\title{
Effects of a Healthy \\ Habit Promotion \\ Strategy on Colombian \\ Schoolchildren*
}

* This study was sponsored by the Universidad de La Sabana and Nestlé, Colombia. After this first stage the study changed its name from "United for Healthy Kids" to "Nestlé for Healthy Kids". Project ENF-35-2019 - Design and Validation of a Reinforcement Intervention Within the Health Promotion Strategy "United By Healthy Children" in Schools of the Sabana Centro Region, 2019

Angélica María Ospina Romero

https://orcid.org/0000-0001-7845-1889 Facultad de Enfermería y Rehabilitación, Universidad de La Sabana. Colombia. angelica.ospina@unisabana.edu.co

\section{Gloria Carvajal Carrascal}

https://orcid.org/0000-0001-8244-2731 Facultad de Enfermería y Rehabilitación, Universidad de La Sabana. Colombia. gloria.carvajal@unisabana.edu.co

Tania Catalina Chinchilla Salcedo

https://orcid.org/0000-0002-6534-6673 Facultad de Enfermería y Rehabilitación,

Universidad de La Sabana. Colombia. tania.chinchilla@unisabana.edu.co

César A. Niño Hernández

https://orcid.org/0000-0001-7510-024X

Facultad de Enfermería y Rehabilitación, Universidad de La Sabana. Colombia. cesar.nino@unisabana.edu.co

凶 Paola Sarmiento González

https://orcid.org/0000-0001-9164-970X Facultad de Enfermería y Rehabilitación, Universidad de La Sabana. Colombia. paola.sarmiento1@unisabana.edu.co

Humberto Mayorga Álvarez

https://orcid.org/0000-0001-8040-0378

Facultad de Enfermería y Rehabilitación, Universidad de La Sabana. Colombia. jhmayorgaa@unal.edu.co 
Theme: Promotion and prevention.

Contribution to the discipline: The positive effect of the "United for Healthier Kids" ( $\mathrm{U}_{4} \mathrm{HK}$ ) strategy on Colombian schoolchildren strengthens health care in schools and responds to one of the most critical health problems worldwide. The $\mathrm{U}_{4} \mathrm{HK}$ promotes healthy nutrition and physical activity habits in schoolchildren, is consistent with the best available evidence, and could be replicated in similar populations, especially in Latin America. 


\section{Abstract}

Chronic non-communicable diseases (CNCD) show an increasing tendency, especially in low- and medium-income countries. It is necessary to develop and evaluate strategies to strengthen healthy habits at an early age in these countries. Objective: To determine the effect of the health promotion strategy "United for Healthier Kids" $\left(\mathrm{U}_{4} \mathrm{HK}\right)$ on health lifestyle habits of a group of Colombian schoolchildren for the 2018-2020 period. Materials and methods: This quasi-experimental study features treatment and control groups and pre- and post-intervention measurements. The study involved 1,011 schoolchildren between six and twelve years old from seven rural and urban schools of the Sabana Centro region of Colombia. We used the Healthy Habits Measurement Tool, previously validated in Colombia. Results: When comparing within and between groups, the UHK strategy showed statistically significant differences in healthy habits $(p<0.05)$ related to nutrition and physical activity in schoolchildren. Conclusions: The $\mathrm{U}_{4} \mathrm{HK}$ strategy had a positive effect and impact on the schoolchildren' healthy habits, especially in the 'chooses to drink water' and 'moves more' components. There were statistically significant differences $(p<0.05)$ between groups in four out of the five categories: drinks more water, chooses nutritios and varied options, eats and cooks as a family, and moves more. The $\mathrm{U}_{4} \mathrm{HK}$ strategy responds to current and future health problems in schoolchildren and helps prevent chronic diseases. It could be replicated in similar populations.

\section{Keywords (Source: DeCS)}

School nursing; public health; health policy; health promotion; nutrition; exercise. 


\section{Efectos de una estrategia de promoción de hábitos de vida saludable en niños colombianos en edad escolar*}

* Este estudio fue patrocinado por la Universidad de La Sabana y Nestlé Colombia. Después de esta primera etapa, el estudio cambió su nombre de "United for Healthy Kids" a "Nestlé for Healthy Kids". Proyecto ENF-35-2019 - Design and Validation of a Reinforcement Intervention Within the Health Promotion Strategy "United By Healthy Children" in Schools of the Sabana Centro Region, 2019.

\section{Resumen}

Las enfermedades crónicas no transmisibles (ECNT) muestran una tendencia creciente, en especial en los países de ingresos bajos y medios. Es necesario desarrollar y evaluar estrategias para fortalecer hábitos de vida saludable en edades tempranas en estos países. Objetivo: determinar el efecto de la estrategia de promoción de la salud "Unidos por niños más sanos" ( $\mathrm{U}_{4} \mathrm{HK}$, por sus siglas en inglés) en un grupo de estudiantes colombianos para el período 2018-2020. Materiales y métodos: este estudio cuasiexperimental cuenta con grupos de tratamiento y control y con mediciones previas y posteriores a la intervención. En el estudio participaron 1011 estudiantes de entre seis y doce años de siete instituciones educativas de Colombia. Se utilizó la Herramienta de medición de hábitos de vida saludable, previamente validada en Colombia. Resultados: al comparar dentro de los grupos y entre ellos, la estrategia $\mathrm{U}_{4} \mathrm{HK}$ mostró diferencias estadísticamente significativas en los hábitos saludables relacionados con la nutrición y la actividad física en niños en edad escolar. Conclusiones: la estrategia $\mathrm{U}_{4} \mathrm{HK}$ tuvo un efecto y un impacto positivo en los hábitos saludables de los estudiantes, en particular en los componentes "beber más agua" y "moverse más". Hubo diferencias estadísticamente significativas $(p<0.05)$ entre los grupos en cuatro de las cinco categorías: beber más agua, variedad y nutrición, comer y cocinar en familia y moverse más. La estrategia $\mathrm{U}_{4} \mathrm{HK}$ responde a los problemas de salud actuales y futuros de los estudiantes y ayuda a prevenir enfermedades crónicas. Además, podría replicarse en poblaciones similares.

\section{Palabras clave (fuente: DeCS)}

Servicios de enfermería escolar; salud pública; política de salud; promoción de la salud; nutrición; ejercicio físico. 


\section{Efeitos de uma estratégia de promoção de hábitos de vida saudável em crianças colombianas em idade escolar*}

Este estudo foi patrocinado pela Universidad de La Sabana e pela Nestlé Colômbia. Após esta primeira etapa, o estudo mudou seu nome de "United for Healthy Kids" a "Nestlé for Healthy Kids". Projeto ENF-35-2019 - Design and Validation of a Reinforcement Intervention within the Health Promotion Strategy "United by Healthy

Children" in Schools of the Sabana Centro Region, 2019

\section{Resumo}

As doenças crônicas não transmissíveis mostram uma tendência crescente, em especial nos países de rendas baixa e média. É necessário desenvolver e avaliar estratégias para fortalecer hábitos de vida saudável de forma precoce nesses países. Objetivo: determinar o efeito da estratégia de promoção de saúde "Unidos por crianças mais saudáveis" ( $\mathrm{U}_{4} \mathrm{HK}$, por sua sigla em inglês) num grupo de estudantes colombianos para o período 2018-2020. Materiais e métodos: este estudo quase experimental conta com grupos de tratamento e controle, e com avaliações prévias e posteriores à intervenção. Do estudo, participaram 1011 estudantes de entre 6 e 12 anos de sete instituições educacionais da Colômbia. Foi utilizada a Ferramenta de avaliação de hábitos de vida saudável, previamente validada na Colômbia. Resultados: ao comparar dentro dos grupos e entre eles, a estratégia $\mathrm{U}_{4} \mathrm{HK}$ mostrou diferenças estatisticamente significativas nos hábitos saudáveis relacionados com a nutrição e a atividade física em crianças em idade escolar. Conclusões: a estratégia $\mathrm{U}_{4} \mathrm{HK}$ teve efeito e impacto positivos nos hábitos saudáveis dos estudantes, em particular nos componentes "beber mais água" e "se movimentar mais". Houve diferenças estatisticamente significativas $(p<0,05)$ entre os grupos em quatro das cinco categorias: beber mais água, variedade e nutrição, comer e cozinhar em família, e se movimentar mais. A estratégia $U_{4} \mathrm{HK}$ responde aos problemas de saúde atuais e futuros dos estudantes e ajuda a prevenir doenças crônicas. Além disso, poderia ser reproduzida em populações semelhantes.

\section{Palavras-Chave (Fonte: DeCS)}

Serviços de enfermagem escolar; saúde pública; política de saúde; promoção da saúde; nutrição; exercício físico. 
The global increase in non-transmissible chronic illness (NTCI) outweighs the capacity of health systems and demands intervention to reduce that load (1). The World Health Organization (WHO) has pointed out the need to reduce risk factors and improve healthy lifestyles (2). One proposed alternative to take on this challenge is the 'health promotion schools' (3). The Pan American Health Organization (PAHO) defines a 'health promotion school' as one that helps children and adolescents to make better decisions regarding their health and the health of the community (4).

Some studies conducted with schoolchildren of higher-income countries have pointed out to a positive response to health promotion strategies (5). In mid and low-income countries such as Colombia, sedentarism (6), overweight $(7,8)$, and cardiovascular risk have continued to increase, with a higher prevalence in schoolchildren from urban areas (9). In the same way, there are dysfunctional family dynamics that increase health risks for schoolchildren (10). Parents' age, educational level, and dietary patterns are associated with the high consumption of sugary drinks (11), while food handling at schools shows unhealthy practices (12). These factors increase the sense of urgency for interventions relating to this matter.

The "United for Healthier Kids" (U4HK) strategy comprises five areas: 1) more water, 2) more managed portions, 3) more fruits and vegetables, 4) more eating and cooking as a family, and 5) more movement. Although this strategy follows the best available evidence and focuses on schoolchildren with their teachers, parents, and school context (13), its effect on Colombian schoolchildren has not been assessed yet. This document shows evidence of the UHK's effect on a group of Colombian schoolchildren.

\section{Materials and methods}

This quasi-experimental quantitative study encompasses pre and post-intervention measurements for treatment and control groups. This research is part of the ProSALUD US 2018-2020 project.

Participants. This study included 1,011 children aged 6 to 12 from seven schools in the Sabana Centro region of Colombia; 682 in the treatment group and 329 in the control group and their parents, teachers, and food service personnel. There were four schools in the treatment group and three in the control group chosen for convenience. All children in the grades we chose participated in the experiment; however, we excluded the measurements of those who had a physical or mental condition that prevented them from answering the questions correctly.

Instruments. We used the healthy lifestyle measurements in schoolchildren tool (HM-HVS-ESC in Spanish), validated in Colombia. The tool has 20 items that assess expertise, attitude, and behavior about nutri- 
tion and physical activity in schoolchildren (14). This tool has versions

for schoolchildren, parents, teachers, and food service personnel.

Procedure. This study took place during a whole school year. We began by requesting informed consent from participating adults, the parent's or tutor's authorization for their child's participation, and the child's approval.

The treatment group received the $\mathrm{U}_{4} \mathrm{HK}$ intervention. As noted above this strategy includes five aspects of health promotion related to nutrition and physical activity.

The control group received a community-guided intervention and included topics such as interpersonal relations, environmental care, and life planning. Both interventions had the same duration and employed similar dynamics. Different groups handled the experiment and measurements, but both followed previously established guidelines. Activities in the $\mathrm{U}_{4} \mathrm{HK}$ intervention included workshops with schoolchildren, learning activities during recess, support for teachers to incorporate these topics into their classes, the promotion of a school garden, and workshops directed towards parents, teachers, shop keepers, and school cafeteria personnel. Treatment and control activities also included workshops with students, learning activities during recess, and voluntary participation by teachers, parents, and school staff.

Analysis. We compared groups between and within them, pre- and post-intervention, using SPSS version 22, by establishing frequency tables and response percentages before and after the intervention. We also analyzed the group through ratio comparison and determined whether the $\mathrm{U}_{4} \mathrm{HK}$ had a positive, negative, or neutral effect on keeping healthy habits.

We then created and calculated an impact index composed of the strategy's ratio of positive change to negative change in knowledge, attitude, and behavior. This means it shows the ratio of positive to negative change when the group is compared before and after the intervention, which is an essential methodological tool to compare results in different time frames.

We made a Chi-squared test to compare treatment and control groups with a confidence interval of $95 \%$ to reject the null hypothesis that a student is equally likely to achieve a determined level of healthy habits regardless of the $\mathrm{U}_{4} \mathrm{HK}$ intervention.

Ethical aspects. This study follows national and international ethical guidelines for health research in human beings. It was reviewed and approved by the institutional ethics committee (Minutes No. 0030518). Researchers were given complete freedom to handle procedures and results with no interference from the sponsoring company. 
Table 1 summarizes the effects and impact of the assessment in schoolchildren who participated in the $\mathrm{U}_{4} \mathrm{HK}$ and indicates each component compared within the group (see Table 1).

Table 1. Effect and impact of the U4HK strategy on Colombian schoolchildren, $2018-2020$

\begin{tabular}{|c|c|c|c|c|c|}
\hline \multirow{2}{*}{ Dimension } & \multirow{2}{*}{$\begin{array}{l}\text { Strategy } \\
\text { component }\end{array}$} & \multirow{2}{*}{ Item } & \multicolumn{2}{|c|}{ Effect (\%) } & \multirow{2}{*}{ Impac } \\
\hline & & & + & - & \\
\hline \multirow{18}{*}{ Nutrition } & \multirow{6}{*}{$\begin{array}{l}\text { Chooses to } \\
\text { drink water }\end{array}$} & Selection of a healthy beverage & 76.4 & 23.6 & 2.79 \\
\hline & & Attitude towards water intake & 80.3 & 19.7 & 0.98 \\
\hline & & Amount of water to be consumed daily & 68.9 & 31.1 & 2.63 \\
\hline & & Importance of water consumption & 87.0 & 13.0 & 1.15 \\
\hline & & Benefits of drinking water & 66.5 & 33.5 & 1.21 \\
\hline & & Component Average & 75.8 & 24.2 & 1.75 \\
\hline & \multirow{3}{*}{$\begin{array}{c}\text { Chooses } \\
\text { nutritious and } \\
\text { varied options }\end{array}$} & Daily food intake & 22.5 & 77.5 & 0.4 \\
\hline & & Benefits of food & 42.9 & 57.1 & 0.7 \\
\hline & & Component Average & 32.7 & $77 \cdot 3$ & 0.5 \\
\hline & \multirow{4}{*}{$\begin{array}{l}\text { Manages } \\
\text { portions }\end{array}$} & Adequate size of portions & 47.1 & 52.9 & 0.60 \\
\hline & & Number of meals per day & 34.8 & 65.2 & 0.69 \\
\hline & & Healthy arrangement of the plate & 41.5 & 58.5 & 0.56 \\
\hline & & Component Average & 41.1 & 58.9 & 0.61 \\
\hline & \multirow{5}{*}{$\begin{array}{l}\text { Enjoys meals } \\
\text { together }\end{array}$} & Attitude towards eating with the family & 83.6 & 16.4 & 1.06 \\
\hline & & $\begin{array}{l}\text { Benefits of preparing foods and eating with } \\
\text { the family }\end{array}$ & $74 \cdot 3$ & 25.7 & 1.13 \\
\hline & & Practice of hand washing & 65.6 & 34.4 & 0.63 \\
\hline & & Order of hand washing & 62.6 & 37.4 & 0.94 \\
\hline & & Component Average & 71.53 & 28.48 & 0.94 \\
\hline \multirow{9}{*}{$\begin{array}{l}\text { Physical } \\
\text { Activity }\end{array}$} & \multirow{9}{*}{ Moves more } & $\begin{array}{l}\text { Regular practice of physical activity, exercise, } \\
\text { or sports }\end{array}$ & 95.4 & 4.6 & 1.3 \\
\hline & & Weekly physical activity & 43.5 & 56.5 & 1.1 \\
\hline & & Hours per day of physical activity & 59.1 & 40.9 & 1.2 \\
\hline & & Benefits of physical activity, exercise, or sports & 53.8 & 46.2 & 0.9 \\
\hline & & $\begin{array}{l}\text { Awareness of the time of physical activity, } \\
\text { exercise, or sports required/day }\end{array}$ & 24.8 & 75.2 & 0.3 \\
\hline & & $\begin{array}{l}\text { Attitude towards physical activity, exercise, or } \\
\text { sports }\end{array}$ & 89.2 & 10.8 & 1.1 \\
\hline & & Weekly distribution of activity time & 49.2 & 50.8 & 0.9 \\
\hline & & Desired weekly distribution of the time of day & 49.1 & 50.9 & 0.9 \\
\hline & & Component Average & 58.0 & 42.0 & 1.00 \\
\hline
\end{tabular}

Source: Research Data, 2018 - 2020.

When comparing groups, we found statistically significant differences $(p<0.05)$ in four of the five proposed $\mathrm{U}_{4} \mathrm{HK}$ categories (see Table 2 ). 
Table 2. $P$-values of the Chi-squared test for difference in knowledge, attitude, and behavior between the treatment and control groups, 2018-2020

\begin{tabular}{|c|l|c|}
\hline \multicolumn{1}{|c|}{$\begin{array}{c}\text { Dimension } \\
\text { Chooses to drink } \\
\text { water }\end{array}$} & \multicolumn{1}{|c|}{ Inter-group compared question } & P-value \\
\hline \multirow{5}{*}{$\begin{array}{c}\text { Chooses nutritious } \\
\text { and varied options }\end{array}$} & Recognizes water consumption as the healthiest beverage & 0.014 \\
\cline { 2 - 3 } & Recognizes the principal benefit of dairy products & 0.000 \\
\hline \multirow{5}{*}{ Moves more } & Frequent practice of physical activity, exercise, or sports & 0.007 \\
\cline { 2 - 3 } & Relates physical activity, exercise, or sports to learning capacity & 0.004 \\
\cline { 2 - 3 } & $\begin{array}{l}\text { Relates physical activity, exercise, or sports to the possibility of } \\
\text { making friends }\end{array}$ & 0.004 \\
\cline { 2 - 3 } & $\begin{array}{l}\text { Diminished time devoted to playing on the tablet, computer, mobile, } \\
\text { or videogames }\end{array}$ & 0.000 \\
\cline { 2 - 3 } & Diminished time meeting with friends with sedentary activity & 0.009 \\
\cline { 2 - 3 } & Applies knowledge of the distribution of time for sedentary activities & 0.004 \\
\hline & Applies knowledge of the distribution of time for sports & 0.003 \\
\hline \multirow{5}{*}{\begin{tabular}{l} 
Enjoys meals together \\
\cline { 2 - 3 }
\end{tabular}} & $\begin{array}{l}\text { Recognizes that cooking and eating with the family helps to organize } \\
\text { family life }\end{array}$ & 0.000 \\
\hline & $\begin{array}{l}\text { Recognizes that cooking and eating with the family helps to eat better } \\
\text { cooking and eating with the family }\end{array}$ & 0.000 \\
\hline & $\begin{array}{l}\text { Recognizes that cooking and eating with the family makes them } \\
\text { feeling good by helping at home }\end{array}$ & 0.001 \\
\hline & Washes hands adequately before eating & 0.000 \\
\hline
\end{tabular}

Source: Research Data, 2018 - 2020.

\section{Discussion}

This study shows that the $\mathrm{U}_{4} \mathrm{HK}$ strategy implemented in schoolchildren aged six through twelve had a positive impact and effect on the 'drinks more water,' 'moves more,' 'chooses nutritious and varied options,' and 'eats and cooks as a family' components. Its findings are similar to those of the Maestra Natura study that included Italian children aged six through 13 (15). In both cases, we have tried to assess a strategy meant for a specific population, and we suggest a continuation of this strategy to achieve a sustainable effect.

The $\mathrm{U}_{4} \mathrm{HK}$ strategy showed improvements in schoolchildren's physical activity beyond what Amornsriwatanakul et al. reported with the strategy they implemented in schoolchildren aged six through 17 in Thailand (16). Similarly, this study highlights the need to sponsor physical activity through public policy; this would make it possible to promote it outside of school settings. 
Some authors report the necessity to include the afterschool period in these health promotion activities. For instance, Rieder et al. carried out a longitudinal three-year study with 76 predominantly Latino schoolchildren in the United States, with pre and post-intervention measurements (17). Their strategy reinforced healthy eating habits, good physical activity, and rest in the afterschool period. Nonetheless, their results vary from those achieved by the $\mathrm{U}_{4} \mathrm{HK}$ strategy in that they only show non-significant improvements in behavior towards food (17).

When Jung et al. evaluated the effectiveness of a program that promotes awareness and healthy food-related behavior in the United States through a quasi-experimental study with 337 primary schoolchildren supported by their teachers, they found statistically significant differences with the treatment group's better performance ( $p<$ 0.05) (18). This study applied a similar nutrition and physical activity guiding frame and achieved similar positive results. However, aside from involving children and their teachers, the $\mathrm{U}_{4} \mathrm{HK}$ strategy also involved parents and school cafeteria staff in reinforcing healthy lifestyles, which respond to unfavorable associations between families, contexts, and healthy habits in schoolchildren (10-12).

In Spain, Gallardo et al. conducted a study with 368 primary school teachers to identify organizational factors influencing schoolchildren's sports practice (19). The authors found that if a wider variety of activities are more oriented towards play, better schoolchildren participation is achieved. Girls value the play component more than boys, and in both cases, teachers' attitude and experience are critical factors for participation in sports (19). It could be a valuable complement for this study to make differentiations by gender and consider different inclusion criteria for teachers to improve the $\mathrm{U}_{4} \mathrm{HK}$ strategy.

Pablos et al. undertook a quasi-experimental study during eight months to evaluate the impact of a healthy lifestyle school program with 158 children aged 10 through 12 (20). Their evaluation included physiological and anthropometric variables, behavior, quality, and frequency of diets, physical activity, rest, and perceived health. Their results showed significant improvements $(p<0.05)$ in triglycerides, glycemia, and oxygen saturation; higher prevalence of normal cholesterol levels, blood pressure, and body mass; better habits and better quality of diet (20). Their findings match those presented by Polo-Ateiza et al., who conducted an intervention for over 20,000 Mexican children in five schools consisting in children participation in supervised medium-effort physical activity for 30 minutes daily, five days a week for a year and achieved a 31.9\% reduction in overweight and obesity indexes, better levels of glycemia and lipidic profile (21). These two studies show a positive effect that agree with our findings. It is vital to continue this line of research with Colombian schoolchildren, incorporating objective measures to evaluate physiological effects of adequate exercise, hydration, and nutrition. 
Taejin et al. examined the effectiveness of the Healthy Highway school program, which promotes awareness and proper behavior regarding healthy nutrition in primary schoolchildren (18). Their results reflect that the strategy was helpful to improve comprehension of the value of adequate nutrition as a factor for good health and improved behavior towards diets that included healthy items by verifying food labels. The $\mathrm{U}_{4} \mathrm{HK}$ strategy differs from this study because it helped children select variety and nutrition, eat and cook as a family, and hydrate well, without considering whether foods are good or bad, but their adequate use and distribution.

It is paramount to continue strengthening the role of schoolchildren as leading actors in their health and that of the community, as suggested by the PAHO and demonstrated by Blunt et al. in Indian schoolchildren. These authors built a young champion community of kids between six and twelve years of age dedicated to promoting healthy practices that modify this growing tendency in $\mathrm{NTCl}(4,22)$.

In any case, these initiatives will require reinforcement and motivation in time, as noted by Nettlefold et al. (23). Their study with students and teachers to promote physical activity and cardiorespiratory capacity found that behavior can improve in the initial phase of these interventions. As emphasized by Ankur et al., positive reinforcement will be a crucial factor for the impact of these strategies to be long-lasting and reduce chronic illness (24).

In short, this research responds to the call to coordinate education and health in school habits, as proposed by Jourdan et al. and Merlo et al. $(25,26)$. The $\mathrm{U}_{4} \mathrm{HK}$ evaluation ratifies the findings of McMullen et al. concerning partnerships between disciplines and sectors of the community being valuable and necessary for health promotion rooted in schools (27).

We consider the schoolyear timeframe a limitation to the study since these health promotion strategies should have continuity over time. We suggest trying longitudinal survey designs that would make it possible to assess the impact and effectiveness of these strategies on the lives of schoolchildren more thoroughly. It is necessary to create more specific variables to determine the effect in different population subgroups. As Love et al. point out, based on their systematic review of 7,963 records of evidence on the effects of physical activity promotion strategies on children aged six through 18 , gender, body mass index, socioeconomic variables, ethnic origin, place of residence, and religion can have varying effects (28).

Assessing these strategies by adding health indexes and variables may be needed, discriminating characteristics by gender or urban versus rural homes to see if these results vary. It would also be helpful to review whether better habits are related to better academic performance, as demonstrated in other studies (29). 
NTCls have a growth rate, especially in low- and mid-income countries such as Colombia. It is necessary to create and evaluate strategies to favor the creation of healthy habits from a young age in these countries. This study showed that the $\mathrm{U}_{4} \mathrm{HK}$ strategy, which comprised 1,011 Colombian schoolchildren aged six through twelve from the Sabana Centro Region, had a positive effect. We supported our measurements on the healthy habits in schoolchildren measuring tool. We rejected the null hypothesis since we found statistically significant differences between the treatment and control groups $(p<0.05)$ in four of the five examined categories: 'drinks more water,' 'chooses nutritious and varied options,' 'eats and cooks as a family,' and 'moves more.' The $\mathrm{U}_{4} \mathrm{HK}$ strategy responds to current and future problems of the schoolchildren population and helps prevent chronic illnesses. It could also be replicated in similar populations.

\section{Acknowledgements}

The authors would like to thank the school community for their decisive participation in this study.

\section{Conflicts of interest: None declared.}

\section{References}

1. Forouzanfar $\mathrm{MH}, \mathrm{Afshin} \mathrm{A}, \mathrm{Alexander} \mathrm{LT}$, Anderson HR, Bhutta ZA, Biryukov S, et al. Global, regional, and national comparative risk assessment of 79 behavioural, environmental and occupational, and metabolic risks or clusters of risks, 19902015: a systematic analysis for the Global Burden of Disease Study 2015. Lancet [Internet]. 2016 Oct;388(10053):1659-724. Available from: https://linkinghub.elsevier.com/retrieve/pii/ So140673616316798

2. World Health Organization. Tackling NCDs: "best buys" and other recommended interventions for the prevention and control of non-communicable diseases [Internet]. Geneva; 2017. Available from: https://apps.who.int/iris/handle/10665/259232

3. World Health Organization. An effective approach to early action on non-communicable disease risk factors [Internet]. Geneva; 2017. Available from: https://apps.who.int/iris/ handle/10665/255625

4. World Health Organization. Promover la salud en la escuela. ¿Cómo construir una escuela promotora de salud? [Internet]. Buenos Aires; 2018. Available from: https://iris.paho.org/ bitstream/handle/10665.2/49146/OPSARG18031-spa. pdf? sequence $=1 \&$ is Allowed $=y$

5. Verjans-Janssen SRB, Gerards SMPL, Kremers SPJ, Vos SB, Jansen MWJ, Van Kann DHH. Effects of the KEIGAAF intervention on the BMI z-score and energy balance-related behaviors of primary school-aged children. Int J Behav Nutr
Phys Act [Internet]. 2020 Dec 17;17(1):105. DOI: https://doi. org/10.1186/s12966-020-01012-8

6. Chalapud-Narváez LM, Molano-Tobar NJ, Ordoñez-Fernández MY. Niveles de sedentarismo de una institución educativa en Popayán, Colombia. Univ y Salud [Internet]. 2019 Aug 30;21(3):198-204. DOI: https://doi.org/10.22267/rus.192103.156

7. Sierra DS, de Miguel ÁG, Yusungaira MVB, Marulanda LC), Tovar LFM, Gutiérrez GAR. Indicadores de protección de la salud en la infancia: Bajo peso, sobrepeso y obesidad en niñas y niños de las escuelas públicas de la ciudad de Neiva-Colombia. REIB Rev Electrónica Iberoam [Internet]. 2018;12(1):182201. Available from: https://dialnet.unirioja.es/servlet/ articulo?codigo $=6833194$

8. Sánchez S, Montaña J, García L, Sánchez J, Rangel L. Actividad física, composición corporal y capacidad músculo-esquelética en adolescentes escolarizados de Floridablanca, Colombia. Rev Cuba Investig Biomédicas [Internet]. 2020;39(1). Available from: http://scielo.sld.cu/scielo.php?script=sci_arttext\&pid=So86403002020000100016\&lng=en\&nrm=iso\&tlng=en

9. Briceño G, Céspedes J, Leal M, Vargas S. Prevalencia de factores de riesgo cardiovascular en escolares de un área rural y urbana de Colombia. Biomédica [Internet]. 2018 Mar 22;38(4). DOI: https://doi.org/10.7705/biomedica.v38i4.4223

10. Paternina Gonzalez DH, Pereira Peñate MM. Funcionalidad familiar en escolares con comportamientos de riesgo psicosocial 
en una institución educativa de Sincelejo (Colombia). Rev Salud Uninort . 2017;33:429-37. DOI: https://doi.org/10.14482/ sun.33.3.10932

11. Ramírez-Vélez R, Fuerte-Celis J-C, Martínez-Torres J, CorreaBautista J-E. Prevalencia y factores asociados al consumo de bebidas azucaradas en escolares de 9 a 17 años de Bogotá, Colombia: Estudio FUPRECOL. Nutr Hosp. 2017;34(2):422-30. DOI: https://doi.org/10.2096o/nh.250

12. Suescún Carrero S, Avila-Panche S. Evaluación microbiológica en programas de alimentación escolar en instituciones educativas en el Departamento de Boyacá - Colombia. Nova [Internet]. 2017 Oct 26;15(28):93. DOI: https://doi. org/10.22490/24629448.2084

13. Nestlé. Nestlé por niños saludables [Internet]. 2017 [cited 2018 Feb 6]. Available from: https://www.nestleporninossaludables.co/

14. Carvajal G, Chinchilla T, Niño C, Sarmiento P, Mayorga J, Sánchez-Herrera B. Validación de la Herramienta de medición de hábitos de vida saludable en escolares, Informe final de investigación. Bogotá D.C.; Universidad de La Sabana; 2018.

15. Scazzocchio B, Varì R, D’Amore A, Chiarotti F, Del Papa S, Silenzi A, et al. Promoting Health and Food Literacy through Nutrition Education at Schools: The Italian Experience with MaestraNatura Program. Nutrients [Internet]. 2021 May 4;13(5):1547. DOI: https://doi.org/10.339o/nu13051547

16. Amornsriwatanakul A, Lester L, Rosenberg M, Bull F. School policies and practices associated with Thai children's overall and domain specific physical activity. PLoS One [Online]. 2021 Jan 22;16(1):e0245906. DOI: https://doi.org/10.1371/journal. pone. 0245906

17. Rieder J, Moon J-Y, Joels J, Shankar V, Meissner P, JohnsonKnox E, et al. Trends in health behavior and weight outcomes following enhanced afterschool programming participation. BMC Public Health [Internet]. 2021 Dec 7;21(1):672. DOI: https:// doi.org/10.1186/s12889-021-10700-4

18. Jung T, Huang J, Eagan L, Oldenburg D. Influence of schoolbased nutrition education program on healthy eating literacy and healthy food choice among primary school children. Int J Heal Promot Educ [Internet]. 2019 Mar 4;57(2):67-81. DOI: https://doi.org/10.1080/14635240.2018.1552177

19. Gallardo A, Conde E, Martinez A, García M. Organizational factors and their influence on participation in the schoolage sports program from the teachers' perspective. J Phys Educ Sport. 2018;18:1265-70. DOI: https://doi.org/10.7752/ jpes.2018.s3188
20. Pablos A, Nebot V, Vañó-Vicent V, Ceca D, Elvira L. Effectiveness of a school-based program focusing on diet and health habits taught through physical exercise. Appl Physiol Nutr Metab [Internet]. 2018 Apr;43(4):331-7. DOI: https://doi.org/10.1139/ apnm-2017-0348

21. Polo-Oteyza E, Ancira-Moreno M, Rosel-Pech C, SánchezMendoza MT, Salinas-Martínez V, Vadillo-Ortega F. An intervention to promote physical activity in Mexican elementary school students: building public policy to prevent noncommunicable diseases. Nutr Rev [Internet]. 2017 Jan 3;75(suppl 1):70-8. DOI: https://doi.org/10.1093/nutrit/nuw047

22. Blunt M, Joseph L, George C, Garner S. Building youth health champions in an Indian subpopulation for non-communicable disease prevention. Health Educ J [Internet]. $2020 \mathrm{Apr}$ 17;79(3):303-14. DOI: https://doi.org/10.1177/0017896919880931

23. Nettlefold L, Naylor P-J, Macdonald HM, McKay HA. Scaling up Action Schools! BC: How Does Voltage Drop at Scale Affect Student Level Outcomes? A Cluster Randomized Controlled Trial. Int J Environ Res Public Health [Internet]. 2021 May 13;18(10):5182. DOI: https://doi.org/10.339o/ijerph18105182

24. Singh A, Bassi S, Nazar GP, Saluja K, Park M, Kinra S, et al. Impact of school policies on non-communicable disease risk factors - a systematic review. BMC Public Health [Internet]. 2017 Dec 4;17(1):292. DOI: https://doi.org/10.1186/s12889-017-4201-3

25. Jourdan D, Gray NJ, Barry MM, Caffe S, Cornu C, Diagne F, et al. Supporting every school to become a foundation for healthy lives. Lancet Child Adolesc Heal [Internet]. 2021 Apr;5(4):295303. DOI: https://doi.org/10.1016/S2352-4642(20)30316-3

26. Michael SL, Merlo CL, Basch CE, Wentzel KR, Wechsler H. Critical Connections: Health and Academics. J Sch Health [Internet]. 2015 Nov 6;85(11):740-58. DOI: https://doi.org/10.1111/ josh.12309

27. McMullen JM, George M, Ingman BC, Pulling Kuhn A, Graham DJ, Carson RL. A Systematic Review of Community Engagement Outcomes Research in School-Based Health Interventions. J Sch Health [Internet]. 2020 Dec 12;90(12):985-94. DOI: https://doi. org/10.1111/josh.12962

28. Love RE, Adams J, van Sluijs EMF. Equity effects of children's physical activity interventions: a systematic scoping review. Int J Behav Nutr Phys Act [Internet]. 2017 Dec 2;14(1):134. DOI: https:// doi.org/10.1186/s12966-017-0586-8

29. Valois RF, Lewallen TC, Slade S, Tasco AN. The ASCD Healthy School Communities project: formative evaluation results. Health Educ [Internet]. 2015 Jun 1;115(3/4):269-84. DOI: https:// doi.org/10.1108/HE-04-2014-0050 